\title{
Two Sides of the Same Coin? \\ Rebalancing and Inclusive Growth in China
}

\author{
Il Houng Lee, Murtaza Syed, and Xin Wang
}




\title{
IMF Working Paper
}

\author{
Asia and Pacific Department \\ Two Sides of the Same Coin? \\ Rebalancing and Inclusive Growth in China \\ Prepared by Il Houng Lee, Murtaza Syed, and Xin Wang ${ }^{1}$ \\ Authorized for distribution by Steven Barnett
}

August 2013

\section{This Working Paper should not be reported as representing the views of the IMF.}

The views expressed in this Working Paper are those of the author(s) and do not necessarily represent those of the IMF or IMF policy. Working Papers describe research in progress by the author(s) and are published to elicit comments and to further debate.

\begin{abstract}
This paper uses the Shapley Value decomposition technique to assess the factors behind the rise of inequality in China. It finds that, in many ways, inequality may have been an inevitable by-product of China's investment and export-led growth model. Between Chinese households, we find that the most important factors explaining income inequality are location, education, access to health insurance, and labor market variables, including the sector of employment and enterprise size. Across China's provinces, divergences in per capita incomes are driven by the relative level of capital-intensity, public spending, financial access, privatization, and urbanization. In addition, excess liquidity may have exacerbated inequality in the last decade, by driving up property prices and the wealth gap. Based on these results, policies that could help broaden the benefits of growth in China include maintaining prudent monetary and credit policies, a more progressive fiscal tax and expenditure system, higher public spending on health and education, deregulation and reforms to increase competition, measures to raise labor incomes and assist vulnerable workers, and better access to finance for both households and SMEs, including in rural areas. Not surprisingly, given the argued nexus between China's growth strategy and inequality, many of these reforms are the same ones that would help rebalance its economy toward consumption and household incomes.
\end{abstract}

JEL Classification Numbers: D31, E21, G18, H5, J30, O15.

Keywords: China, Inclusive Growth, Inequality, Rebalancing.

Authors’ E-Mail Addresses: leeilhoung@gmail.com; msyed@imf.org; wangx2.04@sem.tsinghua.edu.cn

\footnotetext{
${ }^{1}$ Messrs. Lee and Syed are, respectively, the former Senior and current Deputy Resident Representative in the IMF's China office. Mr. Xin is a PhD candidate at Tsinghua University. We would like to thank, without implicating, Professor Chong-en Bai, Steven Barnett, Zhang Bin, He Fan, and seminar participants from Chinese universities, think tanks and government agencies at the IMF-CASS Conference on "China's Growth Model and its Policy Implications" held in Beijing in April for very useful comments.
} 


\section{Contents}

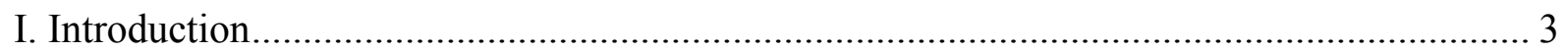

II. Stylized Trends in Poverty and Inequality .............................................................. 5

III. Is Inequality an Inherent Feature of China’s Growth Model? ....................................... 7

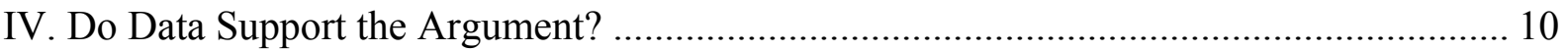

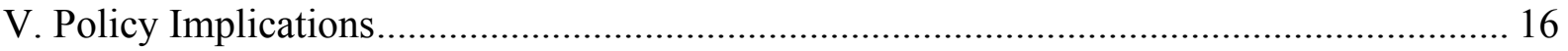

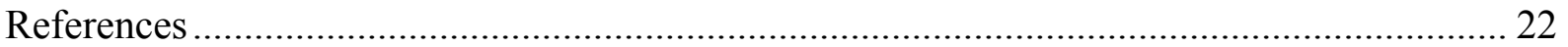

Figures

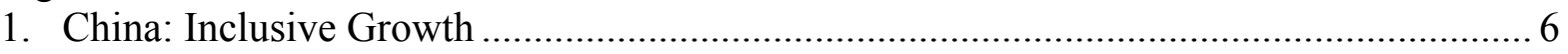

2. China: Provincial Growth Rates ............................................................................ 5

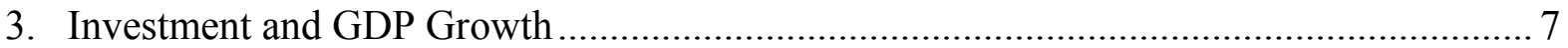

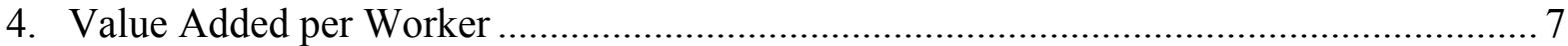

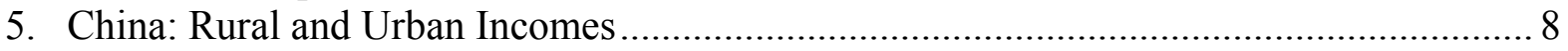

6. Liquidity and Capacity Gap and Asset Prices............................................................... 9

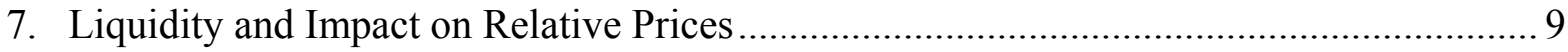

8. China: Government Spending on Coastal Provinces ............................................... 15

Tables

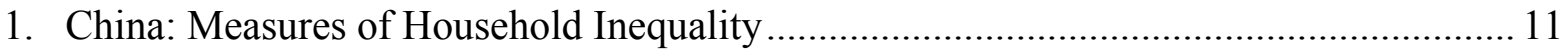

2. Income Generation Function-Household Data ...................................................... 12

3. Decomposition Results — Gini Index of Household Income........................................ 13

4. Ranking of Factors by Alternative Inequality Measures-Household Level .................. 13

5. China: Measures of Provincial Inequality ................................................................... 14

6. Income Generation Function_Provincial Data........................................................ 14

7. Decomposition Results — Gini Index of Provincial Income......................................... 15

8. Ranking Factors by Alternative Inequality Measures: Provincial Level ....................... 16 


\section{INTRODUCTION}

Since its reform and opening up period, China has made remarkable strides in lifting people's incomes and reducing absolute poverty. However, it has come at the cost of rising inequality.

To be sure, rising inequality has been a near global phenomenon in the last two decades, with the important exception of Latin America. Across the globe, there is increasing dissatisfaction with the quality of recent economic growth, which is often seen as benefiting certain groups more than others. This is clearly reflected in rising disparities between different groups, with the rich getting richer faster than the poor. The economics literature has attributed this mainly to globalization, skill-biased technological change and the decreasing bargaining power of workers.

Even within this global setting, however, China's experience stands out. The rise in inequality has been particularly pronounced, leaving China—which was a highly equal society on the eve of its economic reforms - among the most unequal economies in the world. This experience is also a departure from the past record in Asia, presenting a sharp contrast to the three-decade record of equitable growth in Japan, the NIEs and the ASEAN between the 1960s and 1980s. "Growth with equity" was the mantra during this period, as the Asian tigers, unlike Latin America, successfully combined speedy economic growth with relatively low — and in many cases falling — inequality. This ensured that the economic gains from growth were shared widely.

All told, China's growth has been highly pro-poor but less inclusive than in most other developing regions, including Latin America and a number of its Asian peers (Balakrishnan, Steinberg, and Syed, 2013). ${ }^{2}$ This underscores the benefits to China of pursuing a more inclusive growth model. The academic literature and recent events in different parts of the world have highlighted the detrimental impact of high inequality on economic and social stability and the sustainability of growth. ${ }^{3}$

This paper investigates the factors behind inequality in China both across households and between provinces, using the Shapley decomposition technique. It finds that, in many ways, inequality may have been an inevitable by-product of China's investment and export-led growth model. The capital stock was largely utilized to support the growth of the manufacturing sector, increasingly to meet export demand; wages were low in large part due to the large labor dividend; and the East coast developed first for geographical reasons, benefitting from trade and foreign direct investment. The resulting bias toward manufacturing, capital, and urban and coastal regions of the country also seem to have exacerbated the global factors that have given rise to greater inequality across much of the world.

\footnotetext{
${ }^{2}$ There are various ways to interpret what it means for growth to be inclusive and pro-poor. We define the pro-poor nature of growth by its impact on poverty reduction - a metric by which China has been highly successful - and its inclusiveness by whether it ensures that the income share of the bottom quintile of the income distribution does not decline.

${ }^{3}$ See, for example, Berg and Ostry (2011) and Rajan (2010).
} 
This unbalanced growth strategy has in turn propagated income gaps based on skills, sectors, and geography. Between Chinese households, we find that the most important factors explaining income inequality are location, education, access to health insurance, and labor market variables, including the sector of employment and enterprise size. Across China's provinces, divergences in per capita incomes are driven by the relative level of capital-intensity, public spending, financial access, privatization, and urbanization. Importantly, the public sector can also play a powerful role in dampening geographic disparities, as it has done since the "Go-West" policy of 2000. In addition, the rapid growth in liquidity that has increasingly been used to power China's investment may have exacerbated inequality in the last decade. As investment has become relatively less efficient and more reliant on credit expansion, property prices have started to climb, straining affordability. This wealth gap from asset price inflation appears to have further differentiated the income of the rich from the poor, contributing to widening disparities.

Based on our results and international experiences, a number of policies could help broaden the benefits of growth in China. These include maintaining prudent monetary and credit policies, a more progressive fiscal tax and expenditure system, higher public spending on health and education, continued deregulation and reforms to increase competition, measures to raise labor incomes and assist vulnerable workers, and better access to finance for both households and SMEs, including in rural areas. These policies are also in line with recent recommendations by the World Bank and Asian Development Bank (AsDB) for boosting the inclusiveness of China's growth. ${ }^{4}$

In fact, the changes in the growth model envisaged in the $12^{\text {th }}$ Five Year Plan already encompass many of these policies. Thus, our results endorse the policy directions espoused by the government, which would not only help move China to a more balanced growth model but also make this growth more inclusive. More recently, the income distribution plan approved by the State Council further identifies many of the right reform priorities, including minimum wage increases, improving the tax system, and strengthening social security. The remaining challenge will be effective implementation. In addition, fundamental changes, such as rising wages driven by demography, are already in train and could also support the transition to a more equal society.

The rest of this paper is organized as follows. Sections II and III motivate the paper by reviewing some related recent literature and presenting a short overview of trends in poverty

and inequality in China over the last three decades, respectively. Section IV conceptualizes how China's growth model and, more recently, abundant liquidity may have played a key role in propagating inequality. Section $\mathrm{V}$ empirically tests for these effects by analyzing the factors that have contributed to inequality among households and between provinces in China. Section $\mathrm{V}$ concludes with some policy recommendations for making China's growth more inclusive.

\footnotetext{
${ }^{4}$ See World Bank (2012) and Asian Development (2012).
} 


\section{STYLIZEd Trends In Poverty AND INEQUALITY}

When China's reforms began, it was one of the poorest countries in the world. In 1981, nearly 85 percent of its population lived on less than $\$ 1.25$ a day, the fifth-largest poverty incidence in the world. By 2008, this proportion had fallen to 13 percent, well below the developing country average (Figure 1).

This remarkable achievement was facilitated by China's rapid economic growth, which has been highly pro-poor, helping lift more than 500 million people out of poverty within a single generation. Nevertheless, China's large population means that it remains home to almost 175 million people who live in extreme poverty.

Most strikingly, inequality has increased sharply. According to the World Bank, China's Gini index increased from 29 percent in 1981 to over 42 percent in 2005, higher than in the United States. ${ }^{5}$ Notwithstanding a downtick since 2009, official estimates report a Gini index of over 47 in 2012. Many unofficial estimates are even higher. ${ }^{6}$ Wage inequality has increased sharply, as have capital incomes - property and entrepreneurial incomes — which are always more unequally distributed but were virtually insignificant in China prior to its reforms. As a result of this rise in inequality, those in the bottom quintile of the income distribution have not seen their living standards rise as much as others so that their share of overall incomes has fallen. In other words, China's growth has not been as inclusive as in most other emerging regions, including within Asia.

China's rising disparities have been characterized by increases in rural-urban and regional inequality. Estimates suggest that these spatial disparities account for more than half of overall inequality in China (AsDB, 2012). The rural-urban income gap has increased significantly since 1998 , reaching a ratio of more than $3: 1$, which is high by international standards. The ratio has fallen somewhat since 2009 but remains above three. For most other Asian economies, the ratio falls between 1.3-1.8 (Eastwood and Lipton, 2004).

Notwithstanding some decline over the last decade, significant differences in per capita income persist between China's affluent coastal provinces and the rest of the country (Figure 2). For instance, average incomes in Guangdong were two and a half times those in Gansu in 2012.

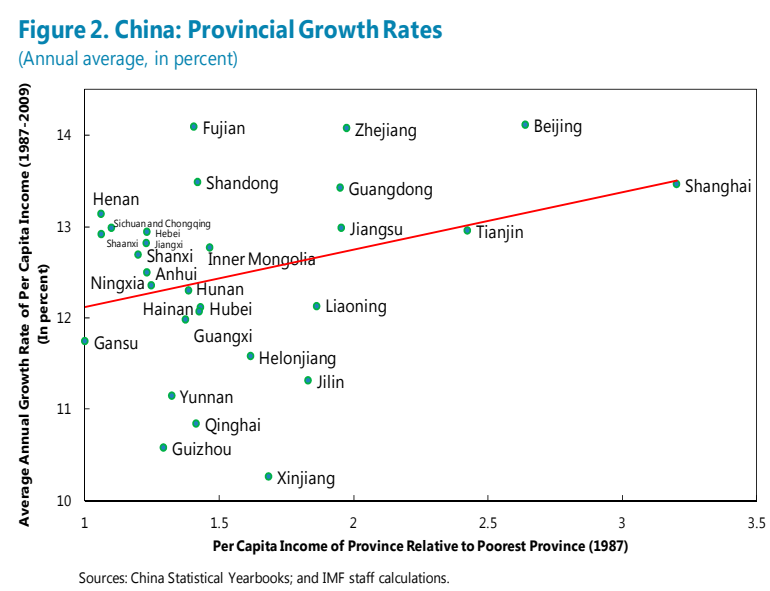

\footnotetext{
${ }^{5}$ The Gini index is a commonly used measure of the extent to which the distribution of income or consumption expenditure within an economy deviates from a perfectly equal distribution. A Gini index of 0 represents perfect equality, while an index of 100 implies perfect inequality (such that one person in the society has all the income).

${ }^{6}$ For instance, a recent study by the China Household Finance Survey Center of Chengdu's Southwestern University of Finance and Economics estimated a Gini of 0.61 in 2010.
} 


\section{Figure 1. China: Inclusive Growth}

\begin{tabular}{|c|c|c|c|c|c|c|}
\hline \multicolumn{7}{|c|}{ Number of People Living on Less than \$1.25/day (at 2005 PPP prices) } \\
\hline & \multicolumn{2}{|c|}{$\begin{array}{l}\text { Percent of } \\
\text { Population }\end{array}$} & \multirow{2}{*}{\multicolumn{2}{|c|}{$\begin{array}{c}\begin{array}{l}\text { Number Percent of } \\
\text { (millions) World Total }\end{array} \\
1990\end{array}$}} & \multirow{2}{*}{\multicolumn{2}{|c|}{$\begin{array}{c}\begin{array}{l}\text { Number Percent of } \\
\text { (millions) World Total }\end{array} \\
2008\end{array}$}} \\
\hline & 1990 & 2008 & & & & \\
\hline Europe and Central Asia & 2 & $<1$ & 9 & $<1$ & 2 & 0 \\
\hline Latin America and the Caribbean & 12 & 6 & 53 & 3 & 37 & 3 \\
\hline Middle East and North Africa & 6 & 3 & 13 & 1 & 9 & 1 \\
\hline Sub-Saharan Africa & 57 & 48 & 290 & 15 & 386 & 30 \\
\hline Asia & 55 & 25 & 1,544 & 81 & 855 & 66 \\
\hline China & 60 & 13 & 683 & 36 & 173 & 13 \\
\hline India & 47 & 33 & 433 & 23 & 395 & 31 \\
\hline Rest of Asia & 58 & 31 & 427 & 22 & 287 & 22 \\
\hline Total & 43 & 22 & 1909 & & 1,290 & \\
\hline
\end{tabular}

Source: World Bank, PovcalNet database.

...making China's growth highly pro-poor.

Income Elasticity of Poverty Reduction ${ }^{1}$

(Impact on poverty headcount, in percent, of 1-percent increase in per capita income)

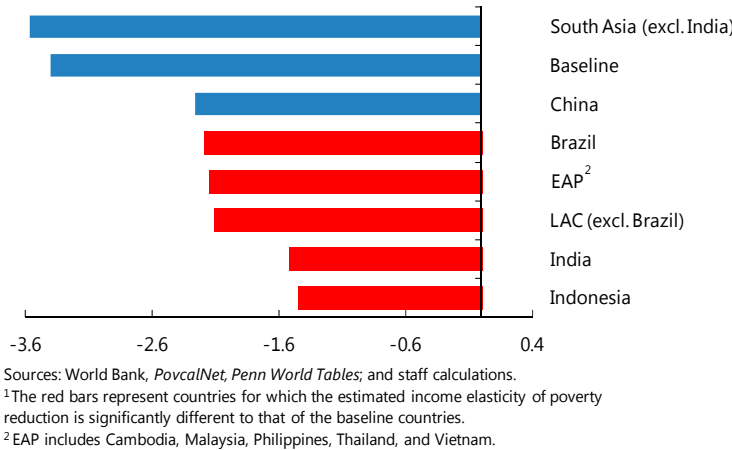

... and much more some than in most other emerging regions...

Asia: Change in Gini Index, Last Two Decades ${ }^{1}$ (In Gini points, since 1990)

China, urban ( 2008, 35.2 )

China, rural ( 2008, 39.4 )

Sri Lanka (2006, 40.3)
Hong Kong SAR $(2011,53.7)$

Indonesia, rural ( $2011,34.0)$

Indonesia, urban ( $2011,42.2$

Lao PDR (2008, 36.7

Singapore $(2010,48.0$
India, urban $(2009,393)$

Japan (2010, 28.7$)$

Bangladesh (2010, 32.1$)$

Korea ( 2010, 34.1
Philippines ( 2009, 43.0

Philippines ( $2009,43.0$

Taiwan Province of China ( $2009,31.7$ )

India, rural $(2009,30.0)$

Malaysia ( 2009, 46.2

Cambodia $(2008,37.9)$

Nepal ( 2010,32.8)

Thailand (2009, 40.0)

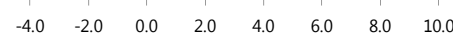

Sources: World Bank; national authorities and IMF staff calculations.

${ }^{1}$ In parentheses, the latest available year and corresponding Gini coefficients. ...which is outstanding by international standards...

Asia: Change in Poverty Headcount, Last Two Decades (In percentage points since 1990)

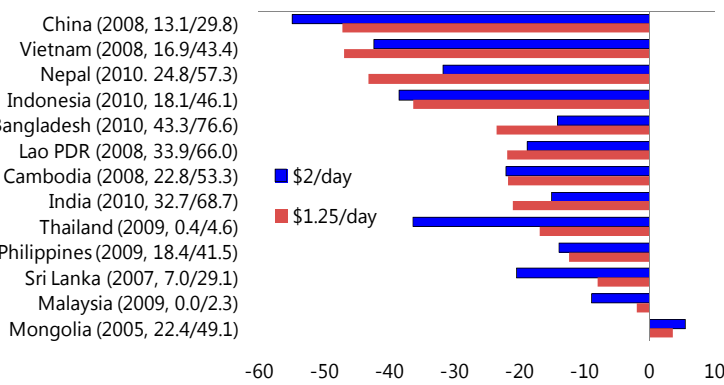

Sources: World Bank; and IMF staff calculations.

${ }^{1}$ At 2005 PPP prices. In parentheses, the latest available year and corresponding poverty headcount ratios at $\$ 1.25$ and $\$ 2$ per day, respectively.

However, inequality has increased markedly over the last two decades...

China: Trends in Poverty and Inequality

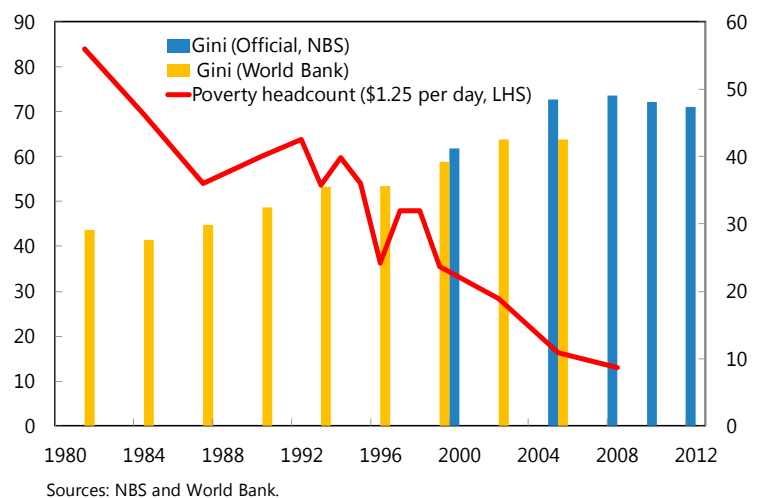

... reducing the inclusiveness of China's growth relative to many of its peers....

Degree of Inclusiveness of Growth ${ }^{1}$

(Impact on income of the bottom quintile, in percent, of a 1-percentincrease in per-capita income)

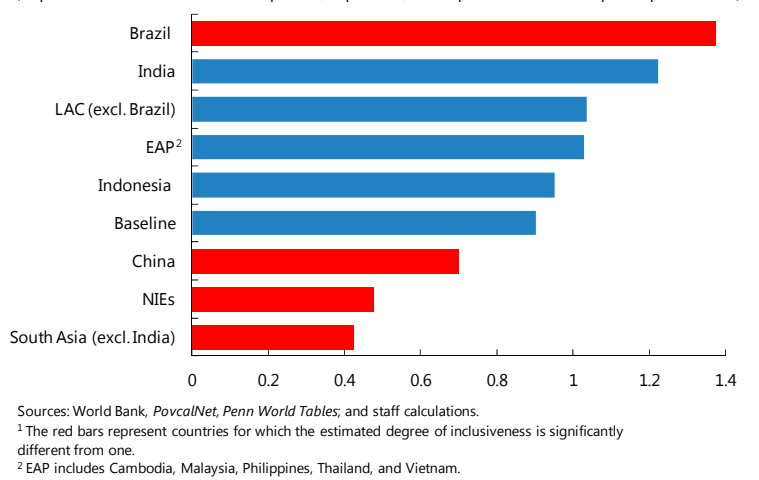




\section{Is INEQUALITY AN INHERENT FEATURE OF ChINA'S Growth MOdel?}

\section{A. China's Growth Model: the Links with Inequality}

To some extent, the model that China has followed in the last three decades has involved a trade-off between rapid rates of growth (and ensuing reductions in absolute poverty) and worsening inequality. ${ }^{7}$ As shown in Figure 3, China's growth model has created wealth through investment-induced capacity growth, largely in the manufacturing sector. Following WTO accession in 2001, this capacity was in large part utilized to meet export demand. Coupled with its large labor dividend (Lee,

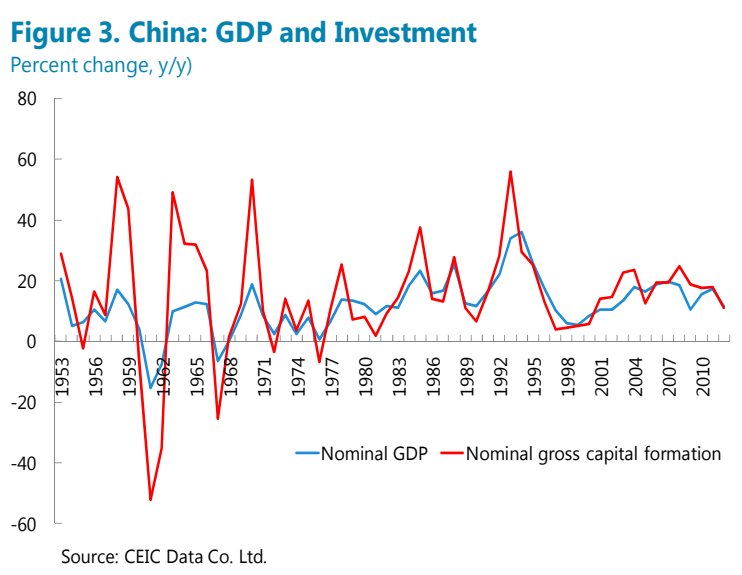
Qingjun, and Syed, 2013a), China was then able to rapidly gain market share at a time when global trade was also booming.

In terms of sectors, rapid capital accumulation in manufacturing kept the value added per worker in the industrial sector high throughout the last few decades (Figure 4). A large share of this value added, however, went to the corporate sector as wages were suppressed by the strong influx of young workers into the labor market associated with China's demographics and the move of migrant workers into urban centers, where industries were concentrated. In addition, by favoring capital, China's investment induced growth model has

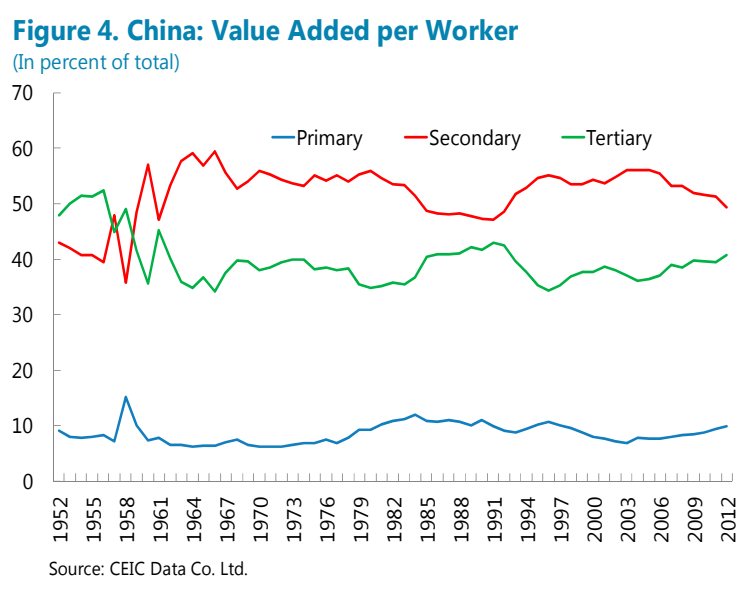
tended to benefit the corporate sector more than workers, and thus less of the benefits of growth accrued to household income (Lee, Syed, and Xueyan, 2013b).

Spatially, the East coast developed first for geographical reasons, benefitting from trade and foreign direct investment, but also as result of preferential policies (Fan, Kanbur, and Zhang, 2009). This unbalanced growth strategy has in turn propagated income gaps based on skills, sectors, and location. Between Chinese households, those who were living in urban centers had access to better education and medical facilities, by virtue of residing in industrialization

\footnotetext{
${ }^{7}$ For more detailed discussions of the links between China's growth strategy and inequality see, among others, Fan, Kanbur, and Zhang, 2009 and Dollar, 2007.
} 
centers where wealth was generated

(Figure 5). Moreover, coastal provinces, China's export heartlands, also provided more opportunities for nonagricultural employment and income. Thus, the historically slower pace of income growth in central and western regions, compared to the export heartlands on China's eastern coast, has widened income gaps between provinces.

Explicit policies also contributed to rising disparities within geographical areas. Due to

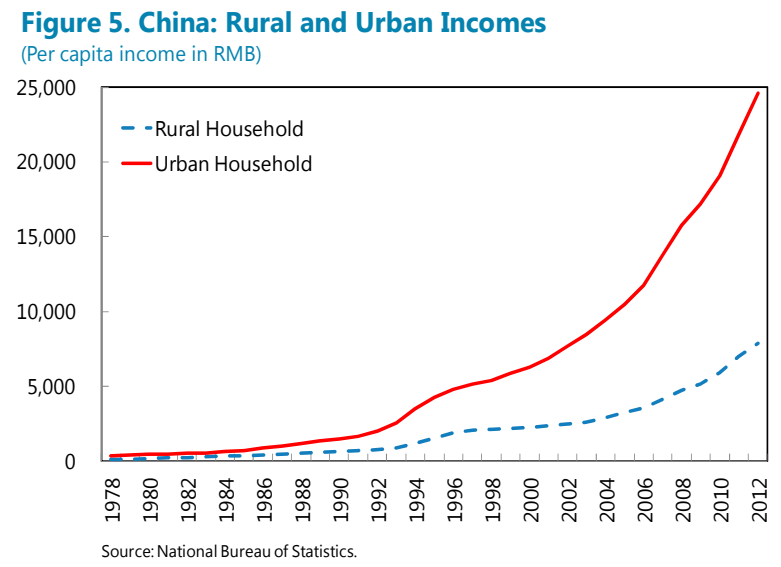
the hukou system, migrant workers had less access to social services. Larger corporations could afford to pay their employees better, not only because of gains from natural economies of scale but also because they enjoyed better and cheaper access to financing under China's state-led banking system. On the positive side, there has been some reversal of this trend in recent years, on the back of supportive government policies in the inland and Western parts of China, minimum wage increases, and an expansion of the social safety net.

Income gaps inevitably emerged under the growth model described above. In sum, rising skill premia pushed up the wages of managers who were in relatively short supply compared to the large influx of young and migrant workers, larger corporations were able to pay better due to stronger competitiveness and better access to finance, those in the manufacturing sector received higher pay than those who remained in the agricultural sector because of productivity differences. Geographically, being at the source of wealth creation, those in urban centers received better wages and social services than in rural areas, while those in the East coast areas prospered relative to inland provinces due to external trade.

\section{B. The Role of Excess Liquidity}

In addition, this model has become more dependent on liquidity rather than productivity gains during the period around the global crisis, exacerbating disparities.

Monetary policies that create excess ${ }^{8}$ liquidity beyond that warranted by cyclical considerations can benefit or harm certain sectors of the economy. As credit expands rapidly, it is typically accompanied by a pickup in economic activity (unless the economy is in a liquidity trap); and on the liability side by a corresponding increase in liquidity. This increase in liquidity should be matched by a corresponding increase in the value of assets. However, if the increase in credit does not translate into productive capital stock, that is, an expansion of

\footnotetext{
${ }^{8}$ Based on the definition proposed by Han and Lee (2012), an excess arises if total liquidity, as defined by the total stock of financial instruments held by the nonfinancial sector, exceeds the total productive capacity of the economy.
} 
productive capacity, then prices will increase due to excess demand. The economy will then only revert back to a steady state condition after this excess liquidity is eliminated through price increases.

Under these circumstances, those who purchased assets with leverage will have gained, those who held assets initially will not be affected, and those whose income is not indexed to inflation (e.g, wage earners) and do not hold assets will have lost. Moreover, this last group will find that the value of their cash savings has declined and the affordability of assets, such as housing, has worsened.

In the United States, this excess liquidity peaked in 2007 at about 20 percent above the economy's productive capacity. It subsequently led to an abrupt adjustment of the stock of liquidity in 2008 and by 2010 this excess was eliminated. However, in doing so, the value of tangible assets deflated sharply, financial institutions underwent painful deleveraging, and the public sector ended up with US\$3.8 trillion more debt, notwithstanding the fact that other factors were at play as well.

In China, this excess is currently about the same level as it was when it peaked in the United States in 2007. The two episodes, 2006-07 and 2008-10, illustrate the potential effects well. During the first episode when liquidity expansion well exceeded the measured capacity, this followed by equity price increase that well exceeded wage increases (Figures 6 and 7). The second episode led to a sharp increase of property prices relative to wage increases. In both scenarios, wage earners were left behind those holding some form of assets.
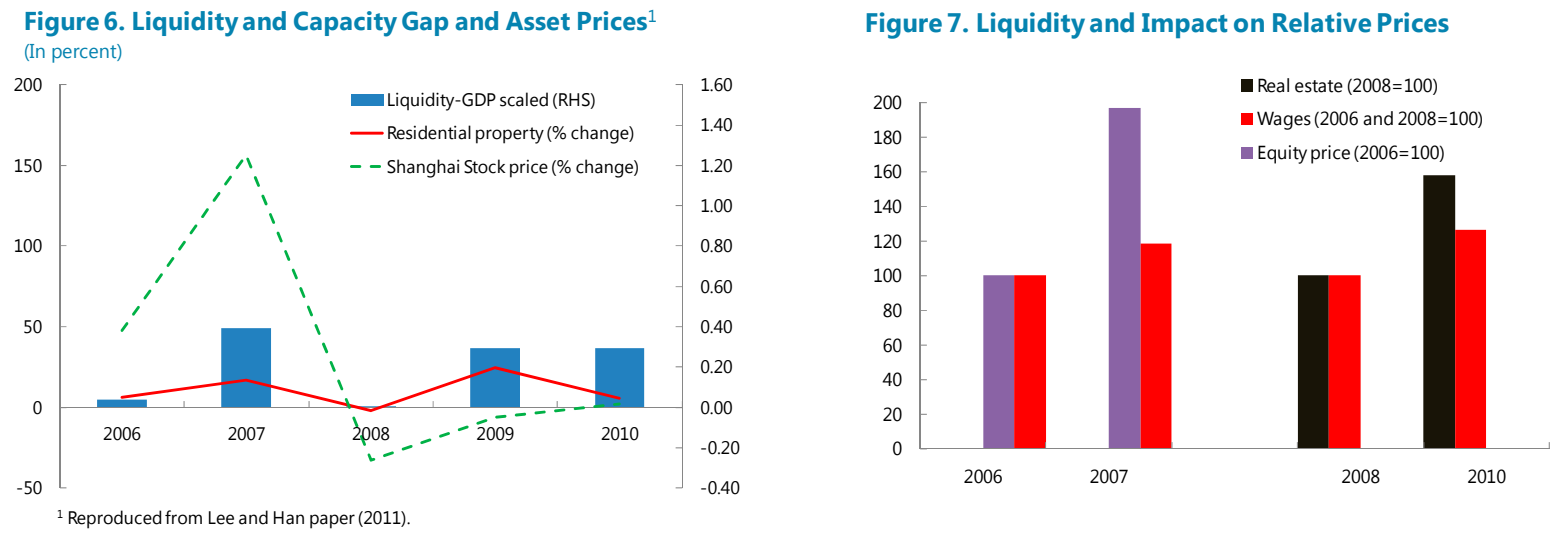

More recently, despite the excess supply of completed property relative to sold floor space, the rapid expansion of total social financing in 2012 have helped support property price increases that could again widen the wedge between wage earners and those who hold assets. This development is similar to the 2003-07 period in the United States where liquidity was in well excess of the productive capacity.

In addition, ample liquidity has facilitated investments in some noncoastal provinces that have become less efficient and wasteful, as elaborated in Lee, Syed, and Xueyan (2013b). This has 
the effect of generating relatively more profit for the corporate sector, with relatively temporary and limited spillover onto household incomes and thus consumption. This also has the effect that individuals and enterprises that have access to liquidity benefit more than those with borrowing constraints, and the latter group may even suffer a loss due to increasing property prices.

Relatedly, if investment efficiency is not improved and excess capacity is gradually eroded through a depreciation of the capital stock. In this case, a corresponding portion of the lost capital will be captured as NPL in financial institutions' balance sheet. This has to be absorbed either by those holding financial assets or by the tax payers. If the latter, those who leveraged up will have again gained at the expense of general households.

Yet another channel through which monetary policy may have inadvertently contributed to inequality is through the transfer of resources from one sector to another, as explained in Lee, Syed, and Xueyan (2012). Through controls in the financial system, resources are transferred from households to the corporate sector, and from SMEs to large corporates. As a result, a large burden of the financing of over-investment is borne by households, estimated at close to 4 percent of GDP per year, while SMEs are paying a higher price of capital because of the funding priority given to larger corporations.

Detecting the impact of such effects of liquidity is difficult to do directly. However, one can test for their importance indirectly, as they would imply that large enterprises should be at an advantage relative to households and SMEs under China's financial controls, wealth should be higher among asset owners and those with access to capital, and provinces with elevated levels of liquidity should see rapid gains in income which, if not translated into capital, will eventually drive a wedge between the rate of credit expansion and growth. Thus, provinces with larger capital stock should have seen greater dividend of growth going to household income. Conversely, if liquidity is used for the purchase of assets only that did not translate into capital, then in those provinces income will tend to be lower as a greater share of growth dividend will have gone to the corporate sector (see Lee, Syed, and Xueyan, 2013b). This is the approach we adopt below.

\section{Do Data Support the Argument?}

Below, we test whether some of the aspects of China's growth model as elaborated above have indeed led to greater income inequality. Acknowledging that data limitations and the complexity of the growth model would not allow us to test all aspects of the causes of inequality, we assess the relative importance of some of the main variables identified in the previous section in explaining inequality. Our analysis is conducted at two levels: between household and across provinces. Our datasets, variables and methodology are described in the Appendix. 


\section{A. Empirical Methods}

To obtain the contribution of individual factors to observed inequality, we adopt the Shapley value procedure of Shorrocks (2012). This procedure addresses shortcomings of older techniques, notably that only certain measures of inequality could be used and simultaneous decomposition into different factors was difficult. In broad terms, the Shapley procedure allows the derivation of an exact additive contribution for each factor to total inequality.

For our empirical exercise, we considered a number of alternative measures of inequality, namely Gini index, the mean log deviation (GE0), ${ }^{9}$ the Theil Index (GE1), ${ }^{10}$ the Atkinson index (ATK), ${ }^{11}$ and the coefficient of variation $(\mathrm{CV}){ }^{12}$ The results presented in the main text are based on the Gini index but the results were qualitatively similar using the other measures. In particular, as discussed below, the rankings of the contribution of our explanatory variables was generally very similar.

Our results provide strong support for the conceptual framework laid out in the previous section, linking a large part of China's inequality to the unbalanced model of growth that it has historically followed—as manifested in terms of the relative importance attached to different aggregate demand components, sectors, enterprises, and locations, including through differential access to credit and finance.

\section{B. Household Level Results}

Based on our dataset drawn from the China Health and Nutrition Survey (CHNS), inequality between households as measured by the Gini index increased from around 38 percent in 1991 to 49 percent in 2009 (Table 1). Broadly similar trends are observed based on alternative measures of inequality. Notwithstanding mild downticks in 1997 and 2009 according to our data, the trend is also very close to that observed in national estimates of the Gini published by the Chinese National Bureau of Statistics.
Table 1. China: Measures of Household Inequality ${ }^{1}$

\begin{tabular}{|c|c|c|c|c|c|c|}
\hline \multirow[t]{2}{*}{ Year } & \multirow{2}{*}{$\begin{array}{r}\text { National } \\
\text { Gini }\end{array}$} & \multicolumn{5}{|c|}{ CHNS Sample } \\
\hline & & Gini & GE0 & GE1 & ATK & $\mathrm{CV}$ \\
\hline 1991 & 32.4 & 37.6 & 27.30 & 23.70 & 11.80 & 74.20 \\
\hline 1993 & 35.5 & 42.4 & 34.90 & 30.90 & 14.90 & 90.50 \\
\hline 1997 & 35.7 & 40.5 & 31.90 & 28.30 & 13.80 & 85.30 \\
\hline 2000 & 41.2 & 44.7 & 40.70 & 35.80 & 17.00 & 102.50 \\
\hline 2004 & 47.3 & 48.2 & 46.00 & 40.80 & 19.20 & 106.90 \\
\hline 2006 & 48.7 & 51.5 & 53.70 & 50.60 & 22.50 & 141.80 \\
\hline 2009 & 49.0 & 48.9 & 48.80 & 45.30 & 20.40 & 129.70 \\
\hline
\end{tabular}

${ }^{1}$ Official data from NBS, except 1991-7, which is from World Bank's PovcalNet System.

\footnotetext{
${ }^{9}$ The mean $\log$ deviation equals to generalized entropy index when $\alpha=0$.

${ }^{10}$ The Theil Index $\left(\mathrm{T}_{\mathrm{T}}\right)$ equals to generalized entropy index when $\alpha=1$.

${ }^{11}$ We take $\varepsilon=0.5$.

12 These indicators are based on different social welfare functions, assume different aversions to inequality, and place different weights on different segments of the underlying income distribution.
} 
As the first step of the Shapley decomposition, an income generating function needs to be estimated. At the household level, we consider the following explanatory variables for income based our conceptual framework: schooling years of the family head (Education), level and quadratic age of the family head to capture life-cycle effects (Age), and dummy variables to capture whether the family head has health insurance (Health), works as a manager (Manager), in a big organization (Scale), or in the agricultural sector (Sector), as well as broad geographic dummies to capture whether the family lives in a coastal province (Coast) and in an urban locality (Urban).

We estimate this function using OLS and find that it explains household income quite well (Table 2). ${ }^{13}$ The signs of the estimated impacts match our intuition and are also economically significant. In 2009, for example, we find that an additional year of schooling for the family head increases household income by around 6 percent. We also detected a life cycle effect on earnings, with household income rising by 2 percent every year during the working life of the family head but falling thereafter. In addition, having a family head that has health insurance, works in a more senior position, outside of agriculture or in a large enterprise all result in significantly higher household income. Location effects are also important, with significantly higher household incomes for households living in coastal provinces or urban areas. In terms of strength, the effects of

\begin{tabular}{|c|c|c|c|c|c|c|c|}
\hline & $\begin{array}{c}(1) \\
1991\end{array}$ & $\begin{array}{c}(2) \\
1993\end{array}$ & $\begin{array}{c}(3) \\
1997\end{array}$ & $\begin{array}{c}(4) \\
2000\end{array}$ & $\begin{array}{c}(5) \\
2004\end{array}$ & $\begin{array}{c}(6) \\
2006\end{array}$ & $\begin{array}{c}(7) \\
2009\end{array}$ \\
\hline Education & $\begin{array}{l}0.017^{\star \star \star} \\
(0.004)\end{array}$ & $\begin{array}{l}0.018^{\star * \star} \\
(0.004)\end{array}$ & $\begin{array}{l}0.027^{\star \star *} \\
(0.004)\end{array}$ & $\begin{array}{l}0.030 * \star * \\
(0.005)\end{array}$ & $\begin{array}{l}0.055^{\star \star \star} \\
(0.005)\end{array}$ & $\begin{array}{l}0.064^{\star \star \star} \\
(0.005)\end{array}$ & $\begin{array}{l}0.062^{\star \star \star} \\
(0.005)\end{array}$ \\
\hline Age & $\begin{array}{l}0.033^{\star \star \star} \\
(0.006)\end{array}$ & $\begin{array}{l}0.024^{\star \star \star} \\
(0.008)\end{array}$ & $\begin{array}{l}0.046^{\star \star \star} \\
(0.007)\end{array}$ & $\begin{array}{l}0.046^{\star \star \star} \\
(0.008)\end{array}$ & $\begin{array}{l}0.022^{\star \star \star} \\
(0.008)\end{array}$ & $\begin{array}{l}0.002 \\
(0.009)\end{array}$ & $\begin{array}{l}0.020^{\star \star} \\
(0.009)\end{array}$ \\
\hline $\mathrm{Age}^{2}$ & $\begin{array}{l}-0.000^{\star \star \star} \\
(0.000)\end{array}$ & $\begin{array}{l}-0.000^{\star \star *} \\
(0.000)\end{array}$ & $\begin{array}{l}-0.000^{\star \star \star} \\
(0.000)\end{array}$ & $\begin{array}{l}-0.000^{\star \star \star} \\
(0.000)\end{array}$ & $\begin{array}{l}-0.000^{*} \\
(0.000)\end{array}$ & $\begin{array}{l}0.000 \\
(0.000)\end{array}$ & $\begin{array}{l}-0.000^{*} \\
(0.000)\end{array}$ \\
\hline $\begin{array}{l}\text { Health insurance } \\
\text { dummy }\end{array}$ & $\begin{array}{l}0.368^{\star \star \star} \\
(0.033)\end{array}$ & $\begin{array}{l}0.329 * \star * \\
(0.041)\end{array}$ & $\begin{array}{l}0.176^{\star \star \star} \\
(0.036)\end{array}$ & $\begin{array}{l}0.387^{\star * *} \\
(0.042)\end{array}$ & $\begin{array}{l}0.452^{\star \star *} \\
(0.038)\end{array}$ & $\begin{array}{l}0.341^{\star \star \star} \\
(0.034)\end{array}$ & $\begin{array}{l}0.361^{\star \star \star} \\
(0.061)\end{array}$ \\
\hline Manager dummy & $\begin{array}{l}0.086^{* *} \\
(0.036)\end{array}$ & $\begin{array}{l}0.098^{* *} \\
(0.044)\end{array}$ & $\begin{array}{l}-0.003 \\
(0.042)\end{array}$ & $\begin{array}{l}0.069 \\
(0.046)\end{array}$ & $\begin{array}{l}0.128^{\star * *} \\
(0.044)\end{array}$ & $\begin{array}{l}0.218^{* \star *} \\
(0.048)\end{array}$ & $\begin{array}{l}0.191^{* * *} \\
(0.048)\end{array}$ \\
\hline $\begin{array}{l}\text { Large enterprise } \\
\text { dummy }\end{array}$ & $\begin{array}{l}0.000 \\
(0.000)\end{array}$ & $\begin{array}{l}0.000 \\
(0.000)\end{array}$ & $\begin{array}{l}0.117^{\star \star \star} \\
(0.042)\end{array}$ & $\begin{array}{l}0.119 * * * \\
(0.044)\end{array}$ & $\begin{array}{l}0.125^{\star \star \star} \\
(0.044)\end{array}$ & $\begin{array}{l}0.146^{\star \star \star} \\
(0.046)\end{array}$ & $\begin{array}{l}0.179 \star \star \star \\
(0.045)\end{array}$ \\
\hline Coast dummy & $\begin{array}{l}0.045 \\
(0.028)\end{array}$ & $\begin{array}{l}0.107^{\star \star \star} \\
(0.035)\end{array}$ & $\begin{array}{l}0.092^{\star \star \star} \\
(0.034)\end{array}$ & $\begin{array}{l}0.216^{\star \star \star} \\
(0.038)\end{array}$ & $\begin{array}{l}0.218^{\star \star \star} \\
(0.038)\end{array}$ & $\begin{array}{l}0.133^{\star \star *} \\
(0.040)\end{array}$ & $\begin{array}{l}0.296^{\star \star \star} \\
(0.038)\end{array}$ \\
\hline Urban dummy & $\begin{array}{l}0.026 \\
(0.032)\end{array}$ & $\begin{array}{l}0.050 \\
(0.039)\end{array}$ & $\begin{array}{l}0.021 \\
(0.038)\end{array}$ & $\begin{array}{l}0.105^{\star \star} \\
(0.041)\end{array}$ & $\begin{array}{l}0.054 \\
(0.039)\end{array}$ & $\begin{array}{l}0.128^{\star \star \star} \\
(0.041)\end{array}$ & $\begin{array}{l}0.193^{\star \star \star} \\
(0.040)\end{array}$ \\
\hline Sector dummy & $\begin{array}{l}-0.452^{\star \star \star} \\
(0.033)\end{array}$ & $\begin{array}{l}-0.478^{\star \star \star} \\
(0.041)\end{array}$ & $\begin{array}{l}-0.470^{* * *} \\
(0.039)\end{array}$ & $\begin{array}{l}-0.472^{\star \star \star} \\
(0.041)\end{array}$ & $\begin{array}{l}-0.386^{\star \star \star} \\
(0.039)\end{array}$ & $\begin{array}{l}-0.338^{\star \star \star} \\
(0.042)\end{array}$ & $\begin{array}{l}-0.268^{\star \star \star} \\
(0.042)\end{array}$ \\
\hline Constant & $\begin{array}{l}5.874 * \star \star \\
(0.144)\end{array}$ & $\begin{array}{l}6.354^{\star * *} \\
(0.194)\end{array}$ & $\begin{array}{l}6.605^{\star \star \star} \\
(0.179)\end{array}$ & $\begin{array}{l}6.532^{\star \star \star} \\
(0.212)\end{array}$ & $\begin{array}{l}6.973^{\star \star \star} \\
(0.218)\end{array}$ & $\begin{array}{l}7.552^{\star \star \star} \\
(0.258)\end{array}$ & $\begin{array}{l}7.334^{\star \star \star} \\
(0.265)\end{array}$ \\
\hline $\begin{array}{l}\text { Village dummy } \\
\text { Observations }\end{array}$ & $\begin{array}{l}\text { No } \\
3568\end{array}$ & No & $\begin{array}{l}\text { No } \\
3488\end{array}$ & No & $\begin{array}{l}\text { No } \\
3868\end{array}$ & $\begin{array}{l}\text { No } \\
3875\end{array}$ & $\begin{array}{l}\text { No } \\
4057\end{array}$ \\
\hline R-squared & 0.26 & 0.20 & 0.19 & 0.24 & 0.25 & 0.23 & 0.19 \\
\hline
\end{tabular}
education, managerial position, enterprise size, and location have increased over time, whereas the effect of age has fallen somewhat.

\footnotetext{
${ }^{13}$ Adding village dummies increased the explanatory power of our model further, but without much impact on the other estimated coefficients and without any derivable policy implications.
} 
In the second step, we estimate the contribution of these factors to inequality in incomes between households in China (Table 3). ${ }^{14} \mathrm{We}$ find that education is currently the most important contributor and its importance has risen sharply over time, accounting for almost

Table 3. Decomposition Results-Gini Index of Household Income

\begin{tabular}{|c|c|c|c|c|c|c|c|c|c|c|}
\hline Year & Education & Age & Health & Manager & Scale & Coast & Urban & Sector & Explained & Gini \\
\hline & \multicolumn{10}{|c|}{ Absolute contribution } \\
\hline 1991 & 0.9 & 4.7 & 3.9 & 0.5 & 0.0 & 0.2 & 0.3 & 5.6 & 16.1 & 37.6 \\
\hline 1993 & 1.1 & 4.3 & 3.2 & 0.5 & 0.0 & 0.4 & 0.4 & 6.1 & 16.1 & 42.4 \\
\hline 1997 & 1.6 & 7.3 & 1.5 & 0.0 & 0.6 & 0.5 & 0.3 & 5.5 & 17.3 & 40.6 \\
\hline 2000 & 1.6 & 6.3 & 3.4 & 0.5 & 0.7 & 1.2 & 0.9 & 5.6 & 20.4 & 44.7 \\
\hline 2004 & 4.2 & 1.8 & 5.1 & 1.0 & 1.1 & 1.8 & 0.7 & 4.9 & 20.7 & 48.2 \\
\hline 2006 & 6.3 & 1.4 & 3.0 & 1.8 & 1.6 & 1.1 & 0.9 & 3.8 & 19.8 & 51.5 \\
\hline \multirow[t]{2}{*}{2009} & 4.8 & 2.4 & 0.5 & 1.4 & 1.8 & 2.2 & 2.0 & 2.8 & 17.7 & 48.9 \\
\hline & \multicolumn{10}{|c|}{ Relative contribution (in percent of explained) } \\
\hline$\overline{1991}$ & 5.6 & 29.1 & 24.3 & 3.2 & 0.0 & 1.4 & 1.9 & 34.5 & $\ldots$ & $\ldots$ \\
\hline 1993 & 6.9 & 26.6 & 20.0 & 3.2 & 0.0 & 2.7 & 2.2 & 38.4 & $\ldots$ & $\ldots$ \\
\hline 1997 & 9.3 & 42.3 & 8.8 & 0.0 & 3.3 & 3.0 & 1.5 & 31.8 & $\ldots$ & $\ldots$ \\
\hline 2000 & 8.0 & 31.0 & 16.8 & 2.6 & 3.7 & 5.9 & 4.4 & 27.6 & $\ldots$ & $\ldots$ \\
\hline 2004 & 20.4 & 8.9 & 24.8 & 4.7 & 5.5 & 8.8 & 3.5 & 23.6 & $\ldots$ & $\ldots$ \\
\hline 2006 & 31.8 & 6.8 & 15.2 & 9.1 & 7.9 & 5.5 & 4.4 & 19.4 & $\ldots$ & $\ldots$ \\
\hline 2009 & 26.9 & 13.2 & 2.6 & 7.8 & 10.2 & 12.2 & 11.1 & 16.0 & $\ldots$ & $\ldots$ \\
\hline
\end{tabular}

one-quarter of the explained variation in incomes. This reflects a growing skills premium.

Age remains an important factor, although its significance has fallen over time as the seniority-based employment structure has been eroded. Access to health insurance and the sector of employment have historically helped explain 40-50 percent of inequality, but the government's efforts to increase the coverage of health insurance in the last few years have significantly reduced the contribution of the former. ${ }^{15}$ Together, disparities in employee seniority and enterprise size account for almost one-fifth of the observed inequality, and these effects have risen sharply over time, particularly since the SOE reforms of the late 1990s. In addition, location effects remain strong, with urban households and those on the coast continuing to have significantly higher incomes. Our results are qualitatively robust to using alternative measures of inequality, including in terms of the overall rankings of the importance of these different factors (Table 4).

Table 4. Ranking of Factors by Alternative Inequality Measures-Household Level ${ }^{1}$

\begin{tabular}{|c|c|c|c|c|c|c|c|c|c|c|c|c|c|c|c|c|c|c|c|c|c|c|c|c|c|c|c|c|c|c|c|c|c|c|c|c|c|c|c|c|}
\hline \multirow{2}{*}{$\frac{\text { Year }}{1991}$} & \multicolumn{5}{|c|}{ Education } & \multicolumn{5}{|c|}{ Age } & \multicolumn{5}{|c|}{ Health } & \multicolumn{5}{|c|}{ Manager } & \multicolumn{5}{|c|}{ Scale } & \multicolumn{5}{|c|}{ Coast } & \multicolumn{4}{|c|}{ Urban } & \multicolumn{6}{|c|}{ Sector } \\
\hline & 4 & 3 & 4 & 5 & 4 & 2 & 6 & 6 & 3 & 2 & 3 & 2 & 2 & 2 & 3 & 5 & 4 & 3 & 4 & 5 & 8 & 8 & 8 & 8 & 8 & 7 & 7 & 7 & 7 & 7 & 6 & 5 & 5 & 6 & 6 & 1 & 1 & 1 & 11 & 1 \\
\hline 1993 & 4 & 3 & 3 & 3 & 4 & 2 & 7 & 7 & 5 & 2 & 3 & 2 & 2 & 2 & 3 & 5 & 4 & 4 & 4 & 5 & 8 & 8 & 8 & 8 & 8 & 6 & 6 & 6 & 7 & 7 & 7 & 5 & 5 & 6 & 6 & 1 & 1 & 1 & 1 & 1 \\
\hline 1997 & 3 & 3 & 3 & 4 & 4 & 1 & 5 & 4 & 2 & 2 & 4 & 2 & 2 & 3 & 3 & 8 & 8 & 8 & 8 & 8 & 5 & 4 & 6 & 5 & 6 & 6 & 6 & 5 & 6 & 5 & 7 & 7 & 7 & 7 & 7 & 2 & 1 & 1 & 1 & 1 \\
\hline 2000 & 4 & 3 & 3 & 3 & 4 & 1 & 8 & 8 & 6 & 2 & 3 & 2 & 2 & 2 & 3 & 8 & 7 & 7 & 8 & 8 & 7 & 6 & 6 & 7 & 7 & 5 & 4 & 5 & 4 & 5 & 6 & 5 & 4 & 5 & 6 & 2 & 1 & 1 & 1 & 1 \\
\hline 2004 & 3 & 3 & 3 & 3 & 3 & 4 & 8 & 8 & 8 & 6 & 1 & 1 & 2 & 1 & 2 & 7 & 6 & 6 & 6 & 7 & 6 & 5 & 5 & 5 & 5 & 5 & 4 & 4 & 4 & 4 & 8 & 7 & 7 & 7 & 8 & 2 & 2 & 1 & 2 & 1 \\
\hline 2006 & 1 & 1 & 1 & 1 & 1 & 6 & 8 & 8 & 8 & 7 & 3 & 3 & 3 & 3 & 4 & 4 & 4 & 4 & 4 & 5 & 5 & 5 & 6 & 5 & 6 & 7 & 6 & 5 & 6 & 3 & 8 & 7 & 7 & 7 & 8 & 2 & 2 & 2 & 2 & 2 \\
\hline 2009 & 1 & 1 & 1 & 1 & 1 & 3 & 8 & 8 & 8 & 7 & 8 & 7 & 7 & 7 & 8 & 7 & 6 & 5 & 6 & 5 & 6 & 4 & 4 & 4 & 4 & 4 & 5 & 6 & 5 & 6 & 5 & 3 & 3 & 3 & 3 & 2 & 2 & 2 & 2 & 2 \\
\hline
\end{tabular}

${ }^{1}$ Numbers indicate ranks by Gini, GE0, GE1, Atkinson Index, and coefficient of variation respectively.

\footnotetext{
${ }^{14}$ Again, the explanatory power of our decompositions could be raised by including village dummies but this was not done because of the lack of policy relevance. This is similar to findings in earlier studies, for instance Wan and Zhou (2005).

${ }^{15}$ Note that there may still be significant differentiation in incomes based on the "level" of this health insurance, but we did not have data to test this.
} 


\section{Provincial Level Results}

At a more aggregated level, using data from the National Bureau of Statistics (NBS), we find that inequality of provincial average incomes has also increased between 1987 and 2009, regardless of which measure of inequality we use (Table 5).

However, the rise is not monotonic, with downticks in the late 1990s (possibly coinciding with SOE reforms) and the late 2000s.
Table 5. China: Measures of Provincial Inequality

\begin{tabular}{llllll}
\hline Year & Gini & GE0 & GE1 & ATK & CV \\
\hline $1987-1990$ & 14.6 & 3.4 & 3.6 & 1.7 & 28.0 \\
$1991-1995$ & 18.3 & 5.2 & 5.6 & 2.7 & 35.2 \\
$1996-2000$ & 17.7 & 5.0 & 5.4 & 2.6 & 34.6 \\
$2001-2005$ & 19.6 & 6.2 & 6.9 & 3.2 & 40.2 \\
$2006-2009$ & 18.8 & 5.8 & 6.4 & 3.0 & 38.5 \\
\hline
\end{tabular}

Again, we first estimate an income generating function at the provincial level, based on the following right-hand side variables, as motivated by our conceptual framework: per capita capital input (Capital), trade/GDP ratio (Openness), the proportion of labor force working in enterprises that are not state owned (Privatization), the proportion of the nonagricultural population (Urbanization), per capita government expenditure (Public spending), per capita bank lending (Financial Access), and location dummies for the Central and West part of China (Location). The per capita variables are expressed in logarithms and all observations are in nominal terms, although the results were robust to deflating by regional consumer price indices.

Estimating the semi-log function using OLS, we find results that are consistent with our conceptual framework (Table 6). Capital intensity, public spending, financial access and urbanization generally tend to have a strong positive influence on provincial per capita incomes. The effect of openness is more ambiguous and smaller, even contributing negatively to incomes during the global crisis, as expected. Meanwhile location effects remain significant, with relatively higher incomes in coastal provinces.

Second, in terms of the actual decompositions of interprovincial inequality, Table 7 shows that financial access, urbanization and privatization have emerged as the three most important contributors, accounting for more than

\begin{tabular}{|c|c|c|c|c|c|}
\hline & $\begin{array}{c}(1) \\
1987-1990\end{array}$ & $\begin{array}{c}(2) \\
1991-1995\end{array}$ & $\begin{array}{c}(3) \\
1996-2000\end{array}$ & $\begin{array}{c}(4) \\
2001-2005\end{array}$ & $\begin{array}{c}(5) \\
2006-2009\end{array}$ \\
\hline Ln(capital) & $\begin{array}{c}-0.035^{\star \star *} \\
(0.012)\end{array}$ & $\begin{array}{l}-0.048^{* *} \\
(0.020)\end{array}$ & $\begin{array}{c}0.007 \\
(0.008)\end{array}$ & $\begin{array}{c}0.020^{\star * *} \\
(0.008)\end{array}$ & $\begin{array}{c}0.024^{\star * *} \\
(0.009)\end{array}$ \\
\hline \multirow{2}{*}{ Ln(public spending) } & 0.068 & 0.075 & $0.193^{\star \star \star}$ & $0.097^{\star \star}$ & $0.185^{\star \star \star}$ \\
\hline & $(0.068)$ & $(0.113)$ & $(0.048)$ & $(0.044)$ & $(0.040)$ \\
\hline Openness & $\begin{array}{l}0.001^{* *} \\
(0.001)\end{array}$ & $\begin{array}{c}0.001 \\
(0.001)\end{array}$ & $\begin{array}{c}0.002^{\star * *} \\
(0.000)\end{array}$ & $\begin{array}{c}0.000 \\
(0.000)\end{array}$ & $\begin{array}{l}-0.001^{*} \\
(0.001)\end{array}$ \\
\hline Privitization & $\begin{array}{c}0.010 * \star \star \\
(0.002)\end{array}$ & $\begin{array}{c}0.019 * \star * \\
(0.004)\end{array}$ & $\begin{array}{c}0.012^{\star \star \star} \\
(0.001)\end{array}$ & $\begin{array}{c}0.013^{\star \star \star} \\
(0.001)\end{array}$ & $\begin{array}{c}0.014^{\star * *} \\
(0.002)\end{array}$ \\
\hline Urbanization & $\begin{array}{c}0.004^{\star \star \star} \\
(0.001)\end{array}$ & $\begin{array}{c}0.008^{\star \star \star} \\
(0.001)\end{array}$ & $\begin{array}{c}0.011^{\star \star \star} \\
(0.001)\end{array}$ & $\begin{array}{c}0.012^{\star \star \star} \\
(0.001)\end{array}$ & $\begin{array}{c}0.008^{\star * *} \\
(0.002)\end{array}$ \\
\hline Ln(financial access) & $\begin{array}{c}0.299 * \star \star \\
(0.060)\end{array}$ & $\begin{array}{c}0.363^{\star \star \star} \\
(0.094)\end{array}$ & $\begin{array}{c}-0.111^{\star *} \\
(0.048)\end{array}$ & $\begin{array}{l}-0.006 \\
(0.044)\end{array}$ & $\begin{array}{l}0.089 * * \\
(0.041)\end{array}$ \\
\hline Center and northeast & $-0.132^{\text {** }}$ & -0.103 & $-0.243^{* * *}$ & $-0.143^{\star \star \star}$ & $-0.068^{*}$ \\
\hline China dummy & $(0.039)$ & $(0.066)$ & $(0.031)$ & $(0.029)$ & $(0.035)$ \\
\hline West China dummy & $\begin{array}{l}-0.067 \\
(0.051)\end{array}$ & $\begin{array}{c}0.065 \\
(0.078)\end{array}$ & $\begin{array}{c}-0.260 * * * \\
(0.036)\end{array}$ & $\begin{array}{c}-0.208^{\star \star \star} \\
(0.033)\end{array}$ & $\begin{array}{c}-0.208^{\star * *} \\
(0.038)\end{array}$ \\
\hline Constant & $\begin{array}{c}4.023^{\star \star \star} \\
(0.270)\end{array}$ & $\begin{array}{c}3.463^{\star \star \star} \\
(0.372)\end{array}$ & $\begin{array}{c}7.016^{\star * *} \\
(0.208)\end{array}$ & $\begin{array}{c}6.579 * \star \star \\
(0.211)\end{array}$ & $\begin{array}{c}5.365^{\star \star *} \\
(0.280)\end{array}$ \\
\hline Observations & 116 & 145 & 145 & 145 & 116 \\
\hline R-squared & 0.83 & 0.75 & 0.92 & 0.95 & 0.94 \\
\hline
\end{tabular}
85 percent of the observed divergence in provincial incomes in the latest period. By contrast, the influence of openness, which used to be an important factor, has receded in strength. 
Capital-intensity remains an important factor, with its influence increasing in the most recent period, leading up to the onset of the global financial crisis. Interestingly, public spending has gone from contributing quite significantly to interprovincial inequality in the late 1980 s and early 1990 s to detracting from it since 2000 . This coincides with the Go-West policy, under which considerable government resources, including both capital and social welfare spending, have been diverted toward inland provinces (Figure 8). It appears that this policy has helped bridge income gaps. Consistent with this, location effects also appear to have weakened somewhat after 2006, suggesting a narrowing of some gaps associated with

Figure 8. China: Government Spending on Coastal Provinces (In percent of total government spending)

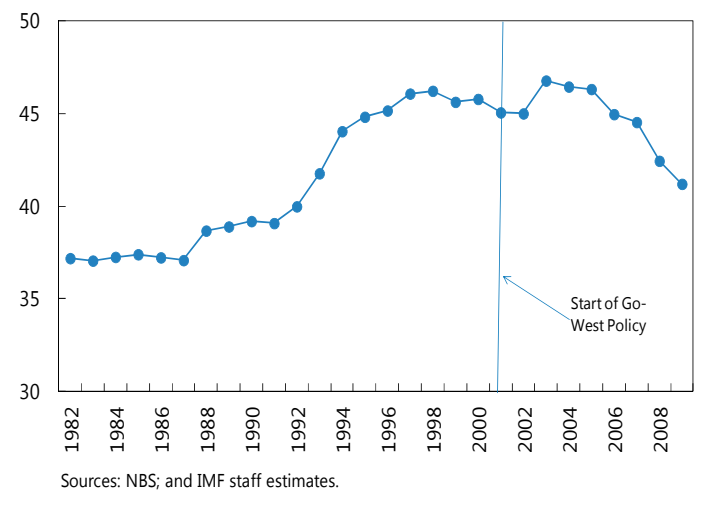
geography (including proximity to markets and infrastructure). ${ }^{16}$

Table 7. Decomposition Results-Gini Index of Provincial Income

\begin{tabular}{|c|c|c|c|c|c|c|c|c|c|}
\hline Year & Capital & Public Spending & Openness & Privitization & Urbanization & $\begin{array}{c}\text { Financial } \\
\text { Access }\end{array}$ & Location & Residual & Gini \\
\hline \multicolumn{10}{|c|}{ Absolute contribution } \\
\hline 1987-1990 & 0.6 & 1.6 & 1.6 & 3.0 & 2.7 & 2.2 & 2.1 & 0.8 & 14.6 \\
\hline 1991-1995 & 1.5 & 1.4 & 2.7 & 3.3 & 5.4 & 0.2 & 2.4 & 1.3 & 18.3 \\
\hline $1996-2000$ & 1.6 & 0.8 & 2.8 & 3.1 & 5.3 & 0.0 & 3.5 & 0.7 & 17.7 \\
\hline $2001-2005$ & 0.8 & -1.3 & 1.5 & 3.6 & 6.5 & 5.3 & 3.3 & -0.1 & 19.6 \\
\hline 2006-2009 & 1.1 & -1.1 & 0.9 & 3.1 & 6.5 & 6.8 & 1.7 & -0.1 & 18.8 \\
\hline \multicolumn{10}{|c|}{ Relative contribution (in percent) } \\
\hline 1987-1990 & 4.1 & 11.1 & 10.8 & 20.5 & 18.6 & 15.2 & 14.3 & 5.4 & $\ldots$ \\
\hline 1991-1995 & 8.1 & 7.2 & 15.2 & 17.7 & 29.6 & 1.7 & 13.5 & 7.1 & $\ldots$ \\
\hline $1996-2000$ & 9.1 & 4.7 & 15.4 & 17.5 & 29.8 & -0.5 & 19.8 & 4.3 & $\ldots$ \\
\hline $2001-2005$ & 4.0 & -6.5 & 7.7 & 18.2 & 33.3 & 27.2 & 16.6 & -0.4 & $\ldots$ \\
\hline 2006-2009 & 6.1 & -6.1 & 4.8 & 16.6 & 34.5 & 35.9 & 8.7 & -0.5 & $\ldots$ \\
\hline
\end{tabular}

Again, we find that the ranking of factors implied by our decomposition of the Gini index are qualitatively robust to using alternative measures of inequality (Table 8). In particular, all the indices show that urbanization, financial access, privatization, and capital-intensity have emerged as the most important contributors to interprovincial inequality in recent years, while the negative influence of openness and public spending has diminished. In addition, all the indices continue to find a role for location.

\footnotetext{
${ }^{16}$ We also tried to include other variables, including dependency ratios and the labor share of income, but their contributions were found to be small conditional on the other variables in our decompositions.
} 
Table 8. Ranking of Factors by Alternative Inequality Measures: Provincial Level ${ }^{1}$

\begin{tabular}{|c|c|c|c|c|c|c|c|c|c|c|c|c|c|c|c|c|c|c|c|c|c|c|c|c|c|c|c|c|}
\hline \multirow{2}{*}{$\frac{\text { Year }}{1987-1990}$} & \multicolumn{8}{|c|}{$\begin{array}{c}\text { Public } \\
\text { Spending }\end{array}$} & \multicolumn{4}{|c|}{ Openness } & \multicolumn{4}{|c|}{ Privitization } & \multicolumn{4}{|c|}{ Urbanization } & \multicolumn{4}{|c|}{$\begin{array}{c}\text { Financial } \\
\text { Access }\end{array}$} & \multicolumn{4}{|c|}{ Location } \\
\hline & 7 & 7 & 7 & 7 & 5 & 2 & 2 & 5 & 6 & 5 & 6 & 6 & 1 & 4 & 4 & 3 & 2 & 1 & 1 & 2 & 3 & 6 & 5 & 1 & 4 & 3 & 3 & 4 \\
\hline 1991-1995 & 5 & 6 & 6 & 4 & 6 & 2 & 2 & 6 & 3 & 5 & 5 & 2 & 2 & 4 & 4 & 3 & 1 & 1 & 1 & 1 & 7 & 7 & 7 & 7 & 4 & 3 & 3 & 5 \\
\hline $1996-2000$ & 5 & 6 & 6 & 4 & 6 & 3 & 3 & 6 & 4 & 5 & 5 & 3 & 3 & 4 & 4 & 5 & 1 & 1 & 1 & 1 & 7 & 7 & 7 & 7 & 2 & 2 & 2 & 2 \\
\hline $2001-2005$ & 6 & 6 & 6 & 6 & 7 & 7 & 7 & 7 & 5 & 5 & 5 & 5 & 3 & 3 & 3 & 4 & 1 & 1 & 1 & 2 & 2 & 4 & 4 & 1 & 4 & 2 & 2 & 3 \\
\hline $2006-2009$ & 5 & 5 & 5 & 4 & 7 & 7 & 7 & 7 & 6 & 6 & 6 & 6 & 3 & 3 & 3 & 3 & 2 & 1 & 1 & 2 & 1 & 2 & 2 & 1 & 4 & 4 & 4 & 5 \\
\hline
\end{tabular}

${ }^{1}$ Numbers indicate ranks by Gini, GEO, GE1/Atkinson Index, and coefficient of variation, respectively.

\section{Policy Implications}

A number of policy implications can be readily derived from our empirical results. Apart from arresting the rising tide of inequality in China, many of these policies have the potential to rationalize savings and boost household incomes, reducing the bias toward capital and large corporates, and unleashing consumption. In this way, they would have the positive side-effect of facilitating the needed rebalancing of China's growth model toward households, workers, and consumption. This is not surprising given the close nexus between inequality and China's investment and export-led growth strategy uncovered through our empirical work. Looking ahead, changing fundamentals like reduction in excess labor (due to population aging) that raises labor incomes and the weaker external environment that further reduces geographical disparities, may naturally induce some greater equity. However, more direct policy interventions are likely to be needed and could include:

More progressive taxes. The redistributive impact of fiscal policy in China may be limited by lower overall levels of both taxes and transfers, which are low compared to other economies at similar levels of development (see, OECD, 2012). In addition, greater reliance on more progressive tax and spending instruments could help (see Bastagli, Coady, and Gupta, 2011) In China, indirect taxes account for three-quarters of tax revenue, compared to less than one-third in advanced economies. Therefore, broadening the tax base and improving the progressivity of some taxes could also be considered in China. ${ }^{17}$

Increasing public spending on education and health. Fiscal spending has been increasing in this area, rising from 18 to 21 percent of total expenditure in the last five years. This is particularly important in the face of rising skill premia and increasing returns to human capital. ${ }^{18}$ However, the existing system of intergovernmental fiscal relations may be complicating progress. Fiscal decentralization is much higher in China than in the OECD and

\footnotetext{
${ }^{17}$ The AsDB notes that only 11 types of personal income are liable to tax. Moreover, while some of these are taxed at progressive rates (wages and salaries), others are taxed at a flat rate (such as incomes of personal services, royalties, and rental and lease incomes).

${ }^{18}$ Between 1988 and 2003, wage returns to one additional year of schooling increased in China from 4 percent to 11 percent (Zhang and others, 2005) and disparities in educational attainment beyond primary school have also emerged.
} 
middle-income countries, particularly on the spending side. More than half of all expenditure takes place at the sub-provincial level, including social spending, but they lack own-revenue sources. As a result, poor villages cannot afford to provide good services, while poor households cannot afford the high private costs of basic public services. In terms of public spending on education, for example, there are large differences in per capita allocations across provinces.

Greater and more targeted public expenditure on social protection. Meanwhile, although China's aging population calls for caution in ensuring the sustainability of pension and health insurance schemes, there may also be scope to increase some welfare spending for equity reasons. Public expenditure on health, pensions, and other forms of social protection only amounts to 5.7 percent of GDP in China. On average, economies at similar levels of development spend more than twice as much. In addition, better targeting could be effective in expanding the coverage of social programs, which according to the AsDB, still do not reach around one-third of the poor in China. In this context, reliance on targeted social expenditures aimed at vulnerable households, including on health and education, could be increased. This includes conditional cash transfer programs that are being increasingly used in low-income emerging economies, notably the highly successful programs in Brazil and Mexico.

Social security reform. In China, combined employee and employer contributions generally top 40 percent of wages, which reduces household disposable income and acts as a disincentive to hiring labor. The rates are higher than in many OECD countries and have an especially hard impact on low-income workers, since it is highly regressive. Lowering these, and compensating for the lost revenue through transfers from the budget would therefore help raise revenue more efficiently, promote rebalancing and also have a positive redistribution effect. Of course, any changes would need to be made in concert with other reforms to strengthen the pension system and ensure its actuarial soundness.

Lowering capital-intensity and boosting the labor share of income. Similar to the rest of the world, the last two decades have seen a decline in the income share of labor and a rise in that of capital - in the case of China, the labor share fell from an estimated 50 percent during the early 1990s to around 40 by the mid 2000s. This contributes to inequality, since capital income tends to be less evenly distributed than income from basic wage labor. This has been exacerbated in the case of China by an artificially low cost of capital and the historically large pool of surplus labor in rural areas. According to the AsDB, employment elasticity of growth between 1991 and 2011 fell from 0.44 to 0.28 in China. Tighter labor markets, financial sector liberalization, and increases in minimum wages should start reversing this trend and raise household income share of GDP. Labor policies to assist vulnerable workers, including through rural employment schemes, reducing labor market duality and removing impediments to labor mobility (such as by reforming the hukou system), as well as worker training and skills upgrading could provide more specific support to the poor. 
Reforms to increase competition. Economic reforms, as proxied by the prevalence of private enterprises, were found to contribute significantly to regional income. This would appear to be particularly important in the services sector, where deregulation and easing entry would help unleash productivity gains. They would also help bridge regional disparities, since the natural geographic features that may affect prospects for manufacturing and trade are likely to be less of a barrier in services, which tend to cater for local populations.

Monetary policy must pay attention to the stock of liquidity and asset prices. Excessive liquidity expansion will not only raise consumer price inflation, but also asset prices. Both increases will leave those who are dependent on wages and salaries, as well as those without wealth in the form of physical and financial assets, relatively worse off. In particular, credit expansion without the corresponding increase in the productive capital stock will worsen the distributional impact of asset price increases and raise the cost of financial intermediation. Thus, a policy that results in an excessive property boom will tend to worsen income and wealth inequality.

Financial sector liberalization is essential to ensure that resources are allocated efficiently and investments generate adequate future household income. Moreover, a well-regulated financial sector will contain excessive risk taking or mispricing of risks, both of which could lead to forced transfer of nonperforming assets from a few to the public to preserve the financial system. Financial market imperfections - such as asymmetric information and costs associated with transactions and contract enforcement—affect the poor and small-scale entrepreneurs most severely, since they typically lack collateral, credit histories, and connections. These impede capital from flowing to poor individuals, even if they have projects with high prospective returns, thereby reducing the efficiency of capital allocation and aggravating inequality. ${ }^{19}$ By addressing these imperfections and creating enabling conditions for financial markets and instruments to develop - such as insurance products that facilitate adjustment to shocks - governments can therefore not only spur growth but also help ensure it is distributed more evenly (see, among others, Beck, Demirguc-Kunt, and Levine (2007).

\footnotetext{
${ }^{19}$ For both China, several empirical studies suggest that uneven access to financial services has contributed to inequality. For instance, Zhang and others (2003) find that after controlling for other factors - such as provincial infrastructure, institutional transition in rural areas, and degree of international integration - differential financial development and urban biases in lending have contributed significantly to the rise in China's urban-rural income disparity since the late 1980 s.
} 


\section{Appendix}

\section{Data}

For the household analysis, we use data from the China Health and Nutrition Survey (CHNS) provided by the Carolina Population Center at the University of North Carolina at Chapel Hill. The dataset covers around 4,000 households in nine provinces: Liaoning, Heilongjiang, Jiangsu, Shandong, Henan, Hubei, Hunan, Guangxi, and Guizhou. The first round of this survey was collected in 1989, however, due to data quality and comparability issues we only use data from its seven additional panels collected in 1991, 1993, 1997, 2000, 2004, 2006, and 2009. We follow the following methods to construct the variables we need:

- $\quad$ Household Income: Per capita household income.

- Education: Schooling years of the family head.

- $\quad$ Age: Age of the family head. We include both linear and quadratic form of age to capture life-cycle effects.

- Health: If the family head has health insurance, Health $=1$; if not, Health $=0$.

- Manager: If the family head works as a manager, Manager $=1$; if not, Manager $=0$.

- Scale: If the family head works in a big organization (more than 20 employees working for the organization), Scale $=1$; if not, Scale $=0$.

- Coast: If the family lives in a coastal province (Jiangsu or Shandong), Coast = 1; if not, Coast $=0$.

- Urban: If the family lives in urban area, Urban $=1$; if not, Urban $=0$.

- Sector: If the family head works in agricultural sector, Sector $=1$; if not, Sector $=0$.

For the provincial analysis ${ }^{20}$, we rely mostly on the China Statistical Yearbook (NBS, various years). The dataset covers 22 provinces, four autonomous regions ${ }^{21}$ and three municipalities ${ }^{22}$ over the period 1987-2009. We follow the following methods for constructing the variables:

\footnotetext{
${ }^{20}$ Our approach is based on Wan, $\mathrm{Lu}$, and Chen (2007) but with a different time period and set of explanatory variables.

${ }^{21}$ As is standard in the literature that uses provincial data in China, we drop Tibet because of a large number of missing observations.

${ }^{22}$ Chongqing (which was separated from the latter in 1997) and Sichuan are treated as a single jurisdiction.
} 
- Income: Weighted average of urban and rural per capita incomes, with nonagricultural and agricultural population shares as weights.

- $\quad$ Capital: Using capital stock data estimated by Zhang (2008), which adopted the perpetual stock method, following the methodology in Zhang, Wu, and Zhang (2004).

- $\quad$ Public Spending: Per capita government expenditure.

- $\quad$ Openness: Trade/GDP ratio.

- $\quad$ Privatization: Proportion of workers and staff in nonstate-owned entities.

- Urbanization: Proportion of nonagricultural population in the total.

- $\quad$ Financial Access: Per capita bank loan.

- $\quad$ Location: Regional Effects.

\section{Empirical Method: Shapley Value Procedure}

Shapley value procedure was introduced to decompose income inequality by Shorrocks (2012).

Let $K$ be a set of explanatory factors, which jointly determine income inequality indicator $I$

$$
I=F(K)
$$

To decompose $I$ to different dimensions of $K$, we must solve

$$
C_{k}=C_{k}(K, F), k \in K
$$

for each $k \in K$ and $C_{k}$ should satisfy two conditions: (1) the symmetric condition, which means $C_{k}$ should not depend on the way in which the factors in $K$ are ranked; and 2) the exact condition, which means

$$
\sum_{k \in K} C_{k}(K, F)=F(K)
$$

One way to define $C_{k}$ is to let

$$
C_{k}=F(K)-F(K \backslash\{k\}), k \in K
$$

This method can satisfy the first condition, but not the exact condition. 
Another method to define $C_{k}$ would be to first give a rank to all the factors in $K$ and then define

$$
C_{k_{n}}=F\left(\left\{k_{n}, k_{n+1}, \ldots, k_{N}\right\}\right)-F\left(\left\{k_{n+1}, \ldots, k_{N}\right\}\right), k_{n} \in K
$$

This method can satisfy the exact condition, but violates the symmetric condition.

Shapley value procedure is a simple revision of the second method. The first step of is to find all possible ways of ranking the factors in $K{ }^{23}$ For each of these, $C_{k_{n}}$ is then calculated using the second method. Finally, the contribution of factor $k$ defined by the Shapley value procedure is the average of all $C_{k_{n}}$ :

$$
C_{k}(K, F)=\frac{1}{N !} \sum_{\sigma \in \Sigma} C_{k_{n}}^{\sigma}
$$

which satisfies both the symmetric and exact conditions.

\footnotetext{
${ }^{23}$ If there are $N$ dimensions in $K$, the total number of possibilities will be $N$ !.
} 


\section{REFERENCES}

Asian Development Bank, 2012, "Outlook 2012: Confronting Rising Inequality in Asia," (Manila).

Balakrishnan, R., C. Steinberg and M. Syed, 2013, "The Elusive Quest for Inclusive Growth: Growth, Poverty, and Inequality in Asia," IMF Working Paper 13/152 (Washington: International Monetary Fund).

Bastagli, F., D. Coady, and S. Gupta, 2011, "Income Inequality and Fiscal Policy,” IMF Staff Discussion Note (Washington: International Monetary Fund).

Beck, T.H.L., A. Demirguc-Kunt, and R. Levine, 2007, "Finance, Inequality and the Poor," Journal of Economic Growth, Vol. 12, No. 1, pp. 27-49.

Berg, A., and J. Ostry, 2011, "Inequality and Unsustainable Growth: Two Sides of the Same Coin?” IMF Staff Discussion Note No. 11/08 (Washington: International Monetary Fund).

Dollar, D., 2007, "Poverty, Inequality and Social Disparities during China's Economic Reform," World Bank Policy Research Working Paper 4253 (Washington: World Bank).

Eastwood, R., and M. Lipton, 2004, "Rural and Urban Income Inequality and Poverty: Does Convergence between Sectors Offset Divergence within Them?" in Inequality, Growth, and Poverty in an Era of Liberalization and Globalization, ed. by G. A. Cornia (Oxford: Oxford University Press).

Fan, S., R. Kanbur, and X. Zhang, 2009, "Regional Inequality in China: An Overview," Regional Inequality in China: Trends, Explanations and Policy Responses, Routledge.

Han, L. and I. Lee, 2012, “Optimal Liquidity and Economic Stability,” IMF Working Paper 12/135 (Washington: International Monetary Fund).

International Finance Corporation, 2010, "Access to Finance: Annual Review Report," (Washington: World Bank).

Jaumotte, F., S. Lall, and C. Papageorgiou, 2008, "Rising Income Inequality: Technology, or Trade and Financial Globalization,” IMF Working Paper 08/185 (Washington: International Monetary Fund).

Lee, I., M. Syed, and L. Xueyan, 2012, “Is China Over-Investing and Does it Matter?" IMF Working Paper 12/277 (Washington: International Monetary Fund).

Lee, I., X. Qingjun, and M. Syed, 2013a, “China's Demography and its Implications," IMF Working Paper 13/82 (Washington: International Monetary Fund). 
Lee, I., M. Syed, and L. Xueyan, 2013b, “China's Path to Consumer-Based Growth:

Reorienting Investment and Enhancing Efficiency," IMF Working Paper 13/83

(Washington: International Monetary Fund).

Liang, Z, 2008, "Financial Development and Income Inequality in Rural China: 1991-2000," in Understanding Inequality and Poverty in China: Methods and Applications, ed. by G. Wan, pp.72-88 (New York: Palgrave Macmillan).

OECD, 2012, "Income Inequality and Growth: The Role of Taxes and Transfers," OECD Economics Department Policy Notes, No. 9. (January).

Rajan, R.G., 2010, Fault Lines: How Hidden Fractures Still Threaten the World Economy (New Jersey: Princeton University Press).

Shorrocks, A. F., 2012, "Decomposition Procedures for Distributional Analysis: A Unified Framework Based on the Shapley Value," Journal of Economic Inequality, Vol. 11, No. 1, pp. 99-126.

Wan, G. and Z. Zhou, 2005, "Income Inequality in Rural China: Regression-based Decomposition Using Household Data," Review of Development Economics, Vol. 9, No. 1, pp.107-20.

Wan, G., M. Lu, and Z. Chen, 2007, “Globalization and Regional Income Inequality: Empirical Evidence From Within China," Review of Income and Wealth, Vol. 53, No. 1, March, pp .35-59.

World Bank, 2012, "China 2030 Report: Building a Modern, Harmonious, and. Creative Society," World Bank and Development Research Center of the State Council, People's Republic of China (Washington).

Zhang, Q., M. Liu, R. Tao, and V. Chen, 2003, "Development of Financial Intermediaries and Urban-Rural Income Inequality in China," (in Chinese), Working Paper (Peking: Peking University).

Zhang J., G. Wu, and J. Zhang, 2004, “The Estimation of China's Provincial Capital Stock: 1952-2000," Journal of Economic Research Vol. 10, pp. 35-44.

Zhang, J., Y. Zhao, A. Park, and X. Song, 2005, "Economic Returns to Schooling in Urban China," Journal of Comparative Economics Vol. 33, pp.730-53.

Zhang, Jun, 2008, "Estimation of China's Provincial Capital Stock (1952-2004) with Applications," Journal of Chinese Economic and Business Studies 6(2), pp 177-96. 